research and development without creating a dearth of teachers in the schools.

\section{Marriage by Consent}

THE greater co-operation between British government research establishments and universities which the Mott committee recommended has found some enthusiastic advocates. The Royal Aircraft Establishment at Farnborough, with the blessing of the Ministry of Aviation, has just concluded an agreement with the University of Southampton which provides for collaboration in teaching, planning and execution of research in the Faculty of Engineering and Applied Science. In practical terms the agreement means that some of the scientists at Farnborough will be co-opted on to the university staff, will receive university titles, and will spend one day each week at Southampton. University research workers will get the benefit of the experience and skill of the Farnborough workers, and will be able to use some of their advanced equipment. Happily, they will not need to obtain security clearance, as the collaboration will cover only unclassified work.

To some extent the agreement only puts into writing informal contacts which have long existed. It would, in fact, be more logical for Farnborough to link up with nearer universities, such as Reading, Oxford and more particularly the new University of Surrey at Guildford, and it is hoped that this will indeed happen in the future.

The General Post Office is also hoping to work in harness with the University of Essex when the Post Office Research Establishment moves to Martlesham in 1969. Already it is conducting a joint research programme with the Medical Research Council's Applied Psychology Unit at Cambridge to discover why people are afraid of the telephone. Co-operation, it seems, is to be encouraged.

It may also be encouraged by the Ministry of Overseas Development. The possibility of a link between the research departments of the ministry and the University of Reading, reported in some British newspapers, is real but as yet unconfirmed. The ministry explains that a decision has not yet been reached about the moving of two of its research establishments, the Tropical Products and Anti-Locust research centres; both of these are at present in Central London. The move contemplated would link them with the Departments of Agricultural Botany, Food Science, and Soil Science at Reading, although it is emphasized that the two centres would retain their identity.

\section{Best Buy in Insulin}

DiABETICS are sometimes affected by sharp falls in their blood sugar concentrations even though they take their insulin regularly. These incidents are unpleasant and could even be fatal in certain situations, as when driving. Most of the cases can be explained as the result of excessive exercise or other known causes, but some of these hypoglycaemic episodes remain unexplained. The medical advisory committec of the British Diabetic Association has now issued a warning about one possible cause of sudden hypoglycaemia. In a letter to The Lancet (ii, 910, 1966) the committee states that "Patients previously treated with ox insulin may, for immunological reasons, respond with increased hypoglycaemia if they are changed unknow- ingly to the same dose of the same pharmacopoeial preparation of pig insulin".

The risk arises because ox insulin differs from pig (and human) insulin at the eighth and tenth aminoacids of its $A$ chain. Pig and human insulin have threonine and isoleucine in these positions, but ox insulin has alanine and valine. The human serum forms antibodies against ox insulin and a proportion of each dose is taken up in ncutralizing the antibodies. If the patient transfers to pig insulin, the antibodies have no effect and the same dose of insulin produces a larger hypoglycaemic effect.

The committee recommends that patients should, as far as possible, be kept on the same brand of insulin. What the advertising agents in other fields call brand loyalty would seem to be a safeguard for diabetics. In Britain, however, nearly all the supply of insulin is taken from cattle, and such pig insulin as there may be comes from abroad. Thus there may even be virtue in that xenophobic slogan "Buy British", at least until the immunology of insulin is better understood.

\section{Lister and Jenner}

Some quixotic streak prompted Lord Florey to begin his lecture on the seventy-fifth anniversary of the foundation of the Lister Institute by talking about Jenner. There was no national memorial to Jenner; although the Lister Institute itself had once been called the Jenner Institute, it had had to abandon the name when it was pointed out that a commercial organization had a prior claim to it. Jenner's house in Cheltenham was about to be demolished. But Lord Florey did suggest a remedy-that international vaccination certificates should show their debt to the inventor of vaccination by carrying Jenner's name and a short description of his work. They are impor. tant documents, said Lord Florey, much more important than passports.

The work of Lister, he said, was a great experiment with man as the subject; no preliminary experiments with animals were ever carried out. This was justified by the appalling mortality rate and by the despair of the surgeons. No one now would wish to return to the simple-minded trials of Lister's day-his controls were the patients who died without his antiseptic treatment. The "sophistication factor" had made modern research very expensive, but advances in understanding were always the result of advances in technique. Medical research workers should not hesitate to spend money-physicists spend more on figurative nuts and bolts than biologists do on electron microscopes.

It was difficult to talk about the influence of Lister on modern thought, he confessed, because he was no longer conversant with all the literature-how could one be ? Even Lister had on occasion missed important papers, and the problem nowadays was even more serious. The simple solution was not to read too much. It always seemed as if everything had already been done; we were too conscious of the literature, too overwhelmed by the priority of discovery. Computers could help by supplying at least the titles of published articles, but conferences were even better. Lord Florey said that scepticism about the value of conferences in exotic places was a thing of the past; we should not be niggardly in supporting small gatherings at which ideas could be exchanged at a personal level. 